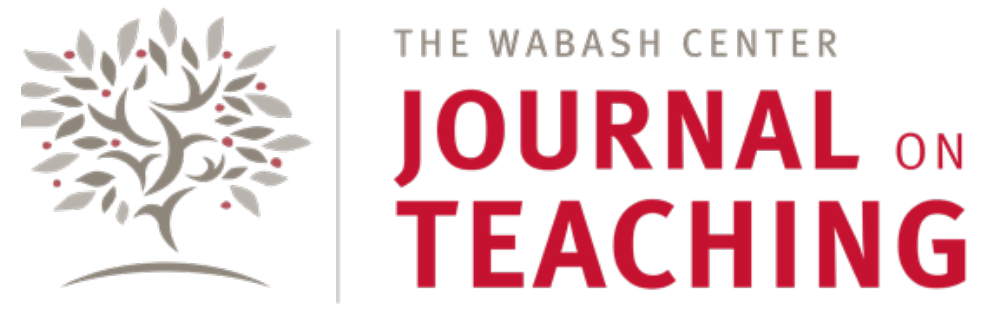

ARTICLE

\title{
Positionality and Disclosure in the Religious Studies Classroom
}

\author{
Kathleen Gibbons \\ Independent Scholar \\ Diane Shane Fruchtman \\ Rutgers University
}

\begin{abstract}
Responsible academic inquiry depends upon our willingness to examine critically the ways in which experience informs scholarly work. In the classroom, however, introducing such examination through direct disclosure poses risk to all students and instructors, especially those of marginalized identities. We argue that the academic study of late antique religions, in its literature and methods, provides opportunities for investigating positionality while circumventing the requirement of such disclosures by classroom participants.
\end{abstract}

KEYWORDS

religious studies, politics, positionality, disclosure, identity

\section{Introduction}

One of the most pervasive and contentious questions that instructors are confronted by is the role of experience in the classroom. Inquiry simply does not happen in the absence of experience. The avenues of investigation that strike us as the most pressing, the data that presents itself to us as relevant, and the inferences and justifications that appeal to our intuitions as more or less plausible than others are all informed by what we, as individuals and as members of wider social groups, have been exposed to, have accessed, and have been shielded from. Such experience does not, moreover, occur outside of the power dynamics that shape our communities and society more broadly, but is conditioned by our location within a nexus of social relations - that is, by our positionality. While responsible teaching and critical investigation depend upon our willingness and ability to scrutinize these power relations and the consequences they bring to bear on our intellectual endeavors, the fact that our experience is inherently political entails that this scrutiny is risky, and more so for some members of our classroom and learning communities than others (see Upson-Saia and Doerfler 2020).

It is imperative to our teaching, then, that we find ways of introducing discussions of experience and identity without requiring any direct disclosures from class participants, student and instructor alike. As teachers and researchers of late 
antique religion, we propose that the content and scholarship of our field offers promising lines of exploration for this purpose. Because "religious identity" refracts through so many other aspects of our lives, the methods and literatures of our discipline have a contribution to make to the examination of positionality and its relationship to epistemology and subject formation. The fact that our objects of study are located in the ancient past can provide a measure of distance that mitigates some of the potential for harm embedded in such examination; yet the ancient world resonates enough with our contemporary environments and communities that its investigation might afford any number of analogues illuminating for our own historical situations. Drawing upon the teaching experiences of participants in our workshop, we offer a series of activities for the classroom that facilitate discussion of the significance of positionality and its role in contouring cognition for inquiry without requiring direct disclosures by instructors or students.

\section{Religious Studies and the Critical Examination of Politics and Positionality}

In the context of a religious studies classroom, or more broadly a classroom for which the academic study of religion makes up a significant component (for example, a classics course incorporating the study of ancient religions), we have the opportunity to consider how the arguments used for critiquing certain popular conceptions of what it means to be "religious," "non-religious," and "secular" might be used to problematize conceptions of "neutrality," "objectivity," "politics," and "the political." That is, just as methods from religious studies problematize the notion that an individual can be entirely divested of "religiosity," so too can these methods facilitate a critique of the idea that an individual of any given identity or combination of identities or experiential backgrounds is free from political, moral, or epistemological bias. ${ }^{1}$

When teaching about late ancient religion we must ask our students to interrogate what religious identity signified at that time: How do we (and how did people of that time) identify discrete communities and defining trajectories of thought or practice? The answer, as it is so often in religious studies, is, "It depends." The reality on the ground, as far as we can gather from the available evidence, was hardly clear or unproblematic. For instance, the earliest surviving list of canonical New Testament books that matches what Christians generally agree on today was drafted only in 367 CE, by the Alexandrian bishop Athanasius (Brakke 1994, 2010b). ${ }^{2}$ If Christians, to the best of our knowledge, could not unanimously agree on a canon of sacred scriptures for three centuries after Paul's death, what was it that defined them as Christians? And what other diversities existed within what would come to be called "Christianity"? ${ }^{3}$ Certainly there was no broad uniformity of practice or doctrine, as clerics jockeyed for doctrinal and ecclesiastical victories at ecumenical councils (Kelly [1958] 2006; Ayres 2004), as leading figures in the church debated what constituted the ethical demands of Christian life (losif 2013; Hunter 2009; Wilhite 2007; Upson-Saia 2011; Upson-Saia, Daniel-Hughes, and Batten 2014), and as practicing Christians found no contradiction in participating in activities we now judge as being "pagan" or "Jewish" (as an example, John Chrysostom felt compelled to instruct his Antiochene parishioners in 386/387 CE that they did not, in fact, need to attend synagogue) (see Drake 2013, 79; Sandwell 2010). In short, among those who identified themselves as Christians in late antiquity, there was no clear consensus about what that label meant-either in terms of what they, as self-identified Christians, should do or believe to perform their Christianity, or about what differentiated them from other identity groups (including Jews and adherents of Hellenistic religions, whose internal heterogeneity is similarly complex) (Boyarin 2006).

Further complicating any attempt to establish a singular concept of religious identity is the larger problem of human identity and its "internal plurality" (Lahire 2001, 36-41). Even if we were to come to some universal definition of what comprises a religious affiliation, religious identity would rarely if ever be a person's only operative identity. The world is simply too complicated and uncontrollable for that to be the case. Our existence as embodied beings, the various demands of our interpersonal relationships and societal structures-in other words, our physical needs (e.g. our particular desires and physical challenges), our human connections (e.g. our familial roles), and the labor by which we survive (e.g. our professional identities)-all prompt identity claims of their own. These various identities often stand in tension with one another, and are rarely able to be thoroughly reconciled by subordinating all competing identities to a singular one through which all others are filtered and by which they are judged-what Handelman terms

\footnotetext{
1 For critical studies of the concept of “religion," see Campany (2003) and Masuzawa (2005); in late antique scholarship, see King (2008), Brakke (2010a, 1-28), and Schott (2008, 1-14)

2 Not only is the late date of an asserted list of canonized texts that might otherwise be taken as immutable or universal an important data point for students, but in a class that has time to focus on the circumstances of the letter's composition, students learn that the letter was written by a man now canonized but deeply controversial during his lifetime, who was writing not strictly for descriptive purposes but as part of a polemic to navigate factions within the Alexandrian church. Indeed, at the time of his writing Festal Letter 39, Athanasius had only recently returned from his fifth exile from Alexandria. This is a good example of how our narratives can mask real-life complexity.

3 Or, as most scholars of the period prefer, in acknowledgement of the diversity of late ancient definitions, "Christianities." For discussion of this terminology, see Brakke (2010a, 7-11).

4 The following discussion of identity is largely inspired by Rebillard (2012) and inquiries into role ethics like those of Cottine (2016). For a critical discussion of the concept of identity, see Berzon (2016).
} 
a "hierarchical arrangement" of category memberships (1977, 191). Rather, identities are often laterally arranged-that is to say, depending on context, one identity will be temporarily foregrounded as the others recede in influence (Handelman 1977, 192-93). We can get a sense of the difficulty and rarity of establishing a hierarchical arrangement for one's identities by looking, once again, to the late antique context. As Rebillard masterfully illustrates, the North African Church in late antiquity was characterized by leaders seeking to impose hierarchical arrangements on Christian communities who habitually tended toward lateral arrangements: As much as Tertullian (fl. 200 CE), Cyprian (d. 258 CE), and Augustine (354-430 CE) advocated for Christianity (as they defined it) to be the only identity that mattered to their audiences, the Christians they were addressing did not "necessarily or consistently" understand their Christian identity to be more significant than their other memberships, affiliations, and identities (Rebillard 2012, 60). Membership in the imperial commonwealth, family ties, neighborhood allegiances, professional obligations, or commitments to other religious or community groups would also have staked claims on a Christian's identity, and the “Christian" identity did not always emerge as most important. Rather, Rebillard shows that Christianity became the most salient identifier for late ancient Christians only episodically-in specific times and situations.

These insights about the fluidity and elusiveness of a purely religious positionality are easily applied to political identities in the present. That is to say, membership in any one category group is never the sole determinant of a person's position in society and their experience of the world, and even when we momentarily train our focus on a single aspect of a person's identity, the internal diversity of the category itself will repel simple conclusions. Our students seem to understand this for themselves-when we ask them to self-reflect, they rarely reduce themselves to a single, labeled identity. Giving them the sense that this same complexity existed in late antiquity is crucial to their understanding of the time period in question, but it also might help them see new axes of difference in the present, for instance by blurring the false boundaries between the religious and the secular or complicating easy distinctions between, for example, Christian, Jew, and Muslim. Indeed, thinking about identities as complex negotiations of varied positionalities dovetails well with intersectionality, a term and idea that many of our students have encountered (if nothing else, as a misunderstood buzzword). Intersectionality demands that we acknowledge a multiplicity of power dynamics and their often amplifying interactions when we consider human experiences (Crenshaw 1989, 1991; Combahee River Collective 2017). By teaching the late ancient material with attention to the complexities of identity construction, on the intersectional model, we help our students problematize simplistic understandings of religious affiliation in a way completely analogous to how they would problematize simplistic understandings of affiliations of other kinds.

Stepping beyond late ancient material to a text that many instructors across the field use in our classrooms, we can also illustrate the parallel problematization of the religious and the political by considering the late Saba Mahmood's Politics of Piety (2004). In this study of the women's mosque movement in Egypt, Mahmood argues that many feminist approaches fail to provide adequate tools for understanding the agency of the women within the movement. Specifically, an understanding of political agency in terms of a simple binary of resistance and subordination in relation to a larger institutional power-in this instance, the secular Egyptian state-does not have the analytical range to fully account for the subject-forming activities of the women of this movement. A number of the women Mahmood considers do not understand their participation in the movement as a way of resisting the state; rather, they talk of practices such as wearing the veil as necessary for the formation of the virtue of modesty. These practices are political because they are deemed by the secular state to encroach upon the distinction between the public and private spheres that it takes as constitutive of its existence: "As theorists of the public sphere have come to recognize, regulation of such quotidian practices is of eminent political concern because they play a crucial role in shaping the civic and public sensibilities essential to the consolidation of a secular-liberal polity" (Mahmood 2004, 73-74). In examining these women's micropractices-performative iterations that shape the agent whose actions embody, reveal, conceal, and contest the social norms and power necessary for the possibility of agency (2004, 55)-Mahmood develops a framework that is potentially illuminating for a number of reasons. ${ }^{5}$ Among these is that her comparative analysis provides an example of how positionality can condition one's conceptual assumptions-in this case, one's conceptions about what flourishing and self-determination require-and how a critical examination of the religious and the political can make those assumptions evident.

Maintaining a reflexive critique that encompasses both our own positionality and that of our subjects is crucial as we examine the late ancient world; the stakes are high, as Kate Wilkinson's work demonstrates (2015). In applying Mahmood's analysis to the practice of modesty among late ancient Christian women, Wilkinson uncovers how scholarly assumptions and failures of imagination have created blind spots in our scholarship and, consequently, our teaching. Following Mahmood's rejection of "resistance" and "subordination" as a simple binary $(2004,29)$, Wilkinson argues that female agency may not always present itself in ways that a contemporary American historian might be conditioned to assume $(2015,22)$. Her proposed solution is one that can be transposed

5 See also Butler: "The forming, crafting, bearing, circulation, signification of that sexed body will not be a set of actions performed in compliance with the law; on the contrary, they will be a set of actions mobilized by the law, the citational accumulation and dissimilation of the law that produces material effects, the lived necessity of those effects as well as the lived contestation of that necessity" (1993, xxi). 
well into the classroom: ethnographic comparison, another signature tool in the "Religious Studies Toolkit." We attempt, as much as possible, to circumvent our epistemological restrictions by considering alternative epistemologies, as well as alternative forms of agency that might "decenter a tacit understanding of the person as a Western, liberal person" (Wilkinson 2015, 26). Wilkinson's call to look to "several different sorts of ... people as possible analogies" is salutary, especially as we, in our capacities as instructors, navigate the tricky terrain of familiarity and foreignness with our students, attempting to help them feel connected to the past without allowing them to overwrite the past with their perceptions of the present (2015, 26; cf. Pagels 1979; Clark 1998; Frank 2000; Brakke 2003; Burrus 2003). While we may not want to ask our students to share their own comparable experiences (see below), by using responsible ethnographic comparanda we can validate the multiplicity of perspectives and imaginaries that might be helpful to analyzing course material, thus subtly sanctioning students' own.

Wilkinson (2015) models the utility of this decentering ethnographic approach by comparing the forms of agency available to late antique women cultivating modesty with those available to women in contemporary South Asian contexts. In analyzing the advice given to the virgin Demetrias and the other Anician women by Augustine, Jerome, and Pelagius in the early fifth century, Wilkinson compares these recommendations not only to evidence for Roman norms regarding domesticity (2015, 58-73), but also to ethnographic data relevant to the South Asian ideal of "purdah" (literally "curtain"), which regulates gender separation inside and outside of the household $(2015,73-84)$. These comparative examples, demonstrating how purdah is an occasion for the exertion of agency and the formation of the person, expand the interpretive possibilities for an American Catholic feminist historian analyzing the works of Demetrias's advisors, particularly given the absence of writings from Demetrias herself (Wilkinson 2015, 26). Wilkinson's comparison of late ancient texts with contemporary ethnographic studies challenges us to examine critically our own assumptions about what agency looks like, and to reexamine what data presents itself as relevant for understanding the material we study and attempt to share with our students.

As shown through each of these examples-considerations of late ancient identity, Mahmood's problematization of agency, and Wilkinson's advocacy of comparative methods-reflecting on positionality can improve both our scholarship and teaching; by explicitly addressing the positionality of both ourselves and our subjects in the classroom, we are not only better able to assess our material, but to share it and make it intelligible to our students. But we are also better able to unpack with our students the nuances and repercussions of various understandings of politics, power, and epistemology, even as we unpack the nuances and repercussions of various understandings of religion.

\section{Positionality and Risk in Self-Disclosures in the Classroom}

Analyses such as those of Mahmood (2004) and Wilkinson (2015), which explore micropractices and their role in establishing, reinforcing, masking, and disrupting norms within fields of power, raise questions for how we might reflect upon and illuminate for our students the operation of positionality in the classroom. We can examine how our own instructional micropractices-the iterative, day-to-day activities that organize classroom sessions, communications with students, and so forth-support, compound, reveal, contest, restructure, or disrupt the power dynamics already present within the learning community. Exploring our and our students' positionality provides a lens through which to interrogate notions of objectivity, interest, and disinterest as well as the assumptions, experiences, and other contingencies at work in their own cognitive frameworks. How does our location within a particular system, or several intersecting systems, of power shape us epistemologically?

Certainly, the response to charges often encountered by those in the academy of bias, irrationality, or a lack of objectivity is not simply for instructors to disclose their own experiences, beliefs, or identities for the sake of transparency and so that students can evaluate if an instructor is inappropriately or speciously interested in a particular subject matter. Doing so would serve only to reify false conceptions of objectivity and disinterestedness, political or otherwise, as either naturally inherent or achievable for individuals of certain backgrounds and affiliations as opposed to others. If an instructor's aim in the classroom is to provide a framework for thinking about how cognition and imagination are shaped by the distribution and exercise of power across a variety of intersecting spheres, attempting to establish their legitimacy as either a knower or an authority figure by appealing to certain identities, experiences, or a lack thereof instead of others undermines that aim. One iteration of such a conundrum is frequently experienced by the instructor of religion, who often must teach while subject to conflicting expectations and assumptions regarding their actual or perceived confessional identity.

Personal disclosures might be incorporated into the classroom, however, as a way of introducing positionality. In such an instance, an instructor might make use of their own experiences and identities as an analytical lens for the purpose of modeling for students that academic claims to objectivity, omniscience, and disinterest are pernicious illusions. There are many axes of categorization on which 
instructors could choose to out themselves and establish their positionality: race, ethnicity, gender, class, religion, sexual orientation and identity, ability, national origin, immigration status, and so forth, all come immediately to mind. Of course, some of these are visible (or otherwise apparent) and some are not. Those that are readily discernible might be performed in a range of ways, either deliberately or not, ${ }^{6}$ but those that are not immediately intelligible might require a verbal disclosure in class, should the instructor wish to include that axis of positionality in the classroom. Such disclosures are no small feat, not to be taken lightly; they are at once necessary and risky-necessary for demystifying the power dynamics at play in the classroom and in the production of knowledge, but risky, as they are predicated on instructors owning our own vulnerability (hooks 1994, 21). We, too, must abandon the illusions of objectivity, omniscience, and disinterest.

The disclosure of experiences that bear on positionality thus opens up its own range of questions and problems. In regard to the question concerning disclosure as a way of mitigating actual or perceived bias, does the suggestion that the instructor do so imply that they have a responsibility to locate themselves across all aspects of their identity? If we reveal one aspect of our positionality, might we be expected to reveal more? Perhaps those most obviously relevant for the subject matter at hand? Further, the very assumption that an instructor could deliberately "disclose" themselves to their students imagines that the instructor's presence is ever presumed to be neutral. This assumption ignores the various ways in which embodiment is always already politicized, where the bodies and voices of some instructors are more apparently politicized than others (Perlow, Bethea, and Wheeler 2014, 243-44; Marbley et al. 2009; hooks 1994, 129-75, 191-99; Sanyal 2011, 127-32). As Perlow, Bethea, and Wheeler explain, "Whereas the bodies of white male professors, their curricula (i.e., works by "great white men”) and pedagogies are normalized, naturalized, and neutralized, those of women and racial minority professors are marked as politicized representations of the Other" (2014, 243). Neither we nor our ideas are ever truly operating on a level playing field: we are always dealing with positionality; we are always dealing with heterodoxy (Fruchtman 2015).

Any expectation that instructors be willing to engage in positionality-focused self-disclosures will have inequitable consequences. Research indicates that for instructors of marginalized identities, particularly visibly marginalized identities, teaching courses overtly related to diversity has negative consequences in comparison to less- or non-marginalized instructors (Gayles et al. 2015; Marbley et al. 2009; Evans and Miller Shearer 2017). These reports indicate that the dynamics operative in society more generally do not cease to inform the activities and structure of the classroom. Just as the presence of those of marginalized identities is frequently perceived as politicized in contexts outside of the academy, so too do students perceive the marginality of their instructors as an indication of a politically biased system that compromises the credibility of those instructors, a perception that can compound with student discomfort in the context of discussions related to diversity (McMillan Cottom 2019, 94). For these instructors in the American higher educational system, we might reasonably conclude that the risk incurred by any such disclosures will be disproportionate in comparison to that incurred by their colleagues.

Given the inequitable levels of risk posed to minoritized faculty members in explicitly disclosing aspects of their positionality, we do not aim to answer the question of whether or not an instructor should disclose either their personal experiences or other aspects of their identity to their students; we aim merely to propose a series of exercises regarding positionality that faculty may want to consider when making their own judgments. We do suggest, however, that any decision on disclosure might be fruitfully complemented with a critical analysis of the idea that one's identity as a learner and a knower can be disclosed or not. How much of such an identity can be confessed in this sense? How is such an identity performed, and what exactly is being asked of instructors who are confronted with the expectation that they present themselves as more neutral? Moreover, what burdens are placed upon other faculty members when an instructor, or group of instructors, claim neutrality or objectivity for their own methodology, viewpoints, and judgments? What might be the consequences of passing, either for the instructor or for the students? ${ }^{7}$

\section{Presenting Positionality in the Religious Studies Classroom}

As an alternative to-or possibly as a way of complementing (at the instructor's discretion)-any self-disclosures, we offer other ways of discussing positionality in the classroom. Rather than relying on course participants to foreground their own experiences and positionalities via self-disclosure, these lesson ideas provide concrete external examples with which students can critique claims and implicit assumptions, both their own and those of others, related to authority, agency, identity, embodiment, scholarly argumentation, and so forth. Such discussions afford an opportunity to explore with students how the interrogation of the social embeddedness of

\footnotetext{
6 Diane Price Herndl (2003) discusses "performing the bimbo" in the wake of her cancer diagnosis and treatment. See, too, the important collection of essays, Being Black, Teaching Black: Politics and Pedagogy in Religious Studies in Westfield (2008).

7 On passing, see Ahmed (2017, 115-34).
} 
cognition, and the implications of this embeddedness for scholarly inquiry, illuminates the conceptions of politics and the political, and the significance of those conceptions for the production of knowledge, that we have argued for in the articles in this issue. These exercises facilitate this exploration by highlighting and scrutinizing the epistemological implications of academic micropractices of citation, categorization, interpretation, and embodied performativity within their larger social contexts.

\section{The Syllabus and the Politics of Citation}

To encourage students to consider the impact of positionality on the classroom and on epistemology more broadly, we can first of all be transparent about our citational practices within the syllabus. Which scholarly voices merit inclusion, and why? What voices do those scholars cite, what sources do they elect to focus on, and what silences do they disrupt or amplify? Why do the readings we have chosen, rather than other possible readings, best facilitate the course objectives? If the voices on our syllabi remain those of scholars with “normalized, naturalized, and neutralized” identities (to borrow Perlow, Bethea, and Wheeler's [2014, 243] phrasing), how might we de-normalize, de-naturalize, and de-neutralize them? Further, discussion about the syllabus itself might be a good opportunity to discuss with students the erasure of scholars of marginalized identities in environments that either tacitly or explicitly presume scholarly authority to be normatively white and male.

One way to diversify our syllabi while embracing the positionality of our students is to invite them to locate materials to add to the syllabus, either as a complement to already assigned readings or on days specifically set aside for student-selected offerings (see also Poey 2011, 87-92; Srikanth 2011, 108; and Dallalfar 2011a, 114). Classroom integration of these materials can range from student-led discussions of the sources they have chosen to a model with far less risk, where, for instance, entirely anonymous contributions are solicited via an online course-management platform and the instructor vets them before planning a class around their use.

\section{Positionality and Categorization}

Instructors can also address positionality by considering names and other forms of categorization; how such categorizations come to exist, be adopted, and be made meaningful; and how terms that might be presumed to be neutral or purely descriptive can take on different meanings, to the point of implying different questions or arguments within the context of different interpretive frameworks. By reflecting on, historicizing, contextualizing, and problematizing the very labels we use in the classroom to discuss groups of people and ideas, instructors can illustrate the ubiquity and importance of positionality, both in history and in contemporary explorations of it.

To allow her students the opportunity to reflect on the imperfect mapping of categorization onto human identity, one workshop participant, an instructor at a large state university, used a reflect-write-share strategy. Her students had been having difficulty understanding how late ancient Christians could disagree with one another about what actions and ethical commitments were required for life as a Christian. Surely one position or the other was wrong, or ill-informed about what real Christianity required? The instructor asked her students to pause; giving them a full minute to silently reflect on their answers, she queried: "What is the first thing you learned about some identity category you belong to? What was the first thing you learned about what it means to be a Christian, a Muslim, an American, whatever?" After the minute had passed, she asked her students to take another five to write down their answers, reflect on them further, and think about how they might help untangle the question of early Christian diversity. Then, the instructor asked if anyone cared to share. Several students who felt comfortable doing so shared their memories-moments from early childhood where a blessing over a meal or a grandmother's habitual "inshallah" or a father's parting words before the first day of school came into focus as uniquely part of a named identity. The students reflected, in response to the instructor's further inquiries, that it was years before snippets like these came to constitute a coherent identity for them, that the memories were inflected with smells and images and emotions that were unique to them and their families, and that every new piece of their identity had to be added to what was already there, lodged in their memory of what it meant to be a member of this group. The instructor then opened discussion to the full class, to ask how this might help us untangle early Christian diversity, and was rewarded with a conversation that treated these ancient people more fully as humans and subjects with their own positionalities and good-faith disagreements about how to live as Christians. It also helped lay the groundwork for future class discussions about the tenability of identifying a pure religion, unaffected by lived human experience.

Other possible exercises might center specifically on historicizing and contextualizing the terms we use, even and especially those that are widely seen as unproblematic. For example, an instructor might incorporate into their class some of the insights of Cynthia Baker's Jew (2017). In tracing some of the developments of the term, Baker observes that it generally originated among Christians, 
often signifying

an absolute other, the very antithesis of the Western Christian self. Almost all modern Western forms of the word-Jew, Jude, juif, Judio, giudeo, jood, Zsidó, etc. (and even the Yiddish word yid)-came into being in decidedly Christian-dominant societies and geopolitical contexts, and, with the exception of yid, they seem often to have taken their earliest written form in commentaries, translations, and sermons on the New Testament by Christians for Christians. (2017, 4)

Jews were thus not only not party to their own naming, but the terms that came to describe them in dominant discourse were developed in settings that explicitly excluded them and that were being mobilized to create and refine another identity, that of the Christian. Introducing our students to this history highlights not just the artificiality of the terminology we use, but the fact that categorization is itself a historical and ideological process, inevitably inflected with political operations. In other words, confronting the history of terminology allows us to denaturalize it with and for our students.

Alongside this historicization, we can discuss with students the continued use of such terms, with the aim of both alerting them to power dynamics of which they might not have been aware and modeling intellectual honesty about the difficulty of these terminological questions. Going back to the example of "Jew," we would note along with Baker that Jew is, according to an analysis by Google of its search data, more likely to be used in an anti-Semitic context than "Jewish," "Judaism," or "Jews" (2017, 10), and that "the Jew" became "the facilitating device for a host of ideological projects" and "a longstanding popular signifier for the contemptible" $(2017,11)$ in a long historical lineage stretching from the Gospel of John to Joseph Goebbels. On the other hand, Baker notes a number of modern Jewish scholars for whom claiming the terminology of "the Jew" and analyzing its construction in history is itself an occasion for the construction of various forms of Jewish agency, identity, and personhood in the context of historical trajectories in which the prerogative to employ these terms has generally been claimed by those who use them to signify others. We can discuss with our students the tricky questions of who gets to define a term, and who gets to claim it, and under what circumstances those designations might come to pass.

For Baker, "translation across the divide is at the heart of the modern project of formulating a sense of Jew as self within a history of the Jew as other" (2017, 75). Understanding the discursive context in which different communities have made use of the designator "Jew" illuminates how a term that many students might take for granted is loaded with a wide range of meaning, such that the variety of interpretive work it performs is conditioned by the positionalities of different speakers. Developing a critical awareness of the scope of this term can destabilize its usage and de-essentialize its meaning. A more detailed understanding of the history of "Jew" as a signifier for self and other provides an occasion for considering how our categorizations do not exist independently of the historical trajectories we use those terms to study while also, ourselves, inhabiting. Other discussions surrounding the relevance of positionality to the polyvalence of meaning might be pursued in the case of any number of other identifiers.

Categorization might also be explored in the classroom through an assignment focusing on larger-scale conceptual formations and their historical contingency. One workshop-generated exercise focused on Saba Mahmood's Politics of Piety (2004) because it presents a positionality-centered critique of doctrinal approaches to religion that also has implications for how we might conceptualize and theorize alternative notions of both the religious and the political. Unpacking her critique and its implications with our students may help them excavate what is being presumed or claimed when objectivity or neutrality are invoked. The lesson plan we developed for encouraging students to think along this trajectory involves dividing students into groups of no more than four and having each group track the experiences, commitments, and arguments of one of Mahmood's (2004) study participants, to see how their positionalities vary. We suggest, in particular, focusing on Nadia and Sana, two women who, on Mahmood's account, offer different critiques of Egyptian attitudes towards marriage, particularly those that shamed women for remaining unmarried despite the fact that it was considered improper for them to propose marriage to men. In practice, this and similar exercises work best when there are multiple groups tracking each participant, so this exercise is scalable to even large lecture classes incorporating some elements of active learning.

The reason we suggest focusing on Nadia and Sana is because, despite divergent positionalities, they nonetheless come to similar assessments of Egyptian marriage norms. Nadia, a participant in the mosque movement, understood her response to the difficulties she experienced as a consequence of these attitudes-particularly with regards to her family prior to her marriage at the age of thirtyfour-in terms of the cultivation of the virtue şabr, or perseverance. She held this virtue as necessary to exercise "first and foremost because it is an essential attribute of a pious character, an attribute to be cultivated regardless of the situation one faces" (Mahmood 2004, 172). Şabr in this sense was therefore not a virtue she understood herself to develop "in resistance" to her experience, but was the character trait that conditioned her response to her circumstances. Sana, on the other hand, was a self-identified secular Muslim and a single professional who responded to these social pressures by developing self-esteem in relation to her career (Mahmood 
2004, 172). Both women, however, recognized the social punishment experienced by unmarried women as an injustice:

Just as the practice of self-esteem structured the possibilities of action that were open to Sana, so did the realization of şabr for Nadia, enabling certain ways of being and foreclosing others. ... What Nadia's and Sana's discussions reveal are two different modes of engaging with social injustice, one grounded in a tradition that we have come to value, and another in a nonliteral tradition that is being resuscitated by the movement I worked with. (Mahmood 2004, 174)

Mahmood is here making the case for an open-ended approach to feminist scholarship, arguing that the women's mosque movement provides an opportunity to reflect specifically on the limitations of those forms of feminist inquiry that naturalize liberal notions of agency. ${ }^{8}$ Going through her discussion of the details of the lives of Nadia and Sana allows students to consider (1) how each understood the ramifications of being a Muslim and a woman for her own life; (2) how an analysis of these self-understandings required attention not only to the beliefs, but also to the micropractices of the actors of their environments, both their own and those around them; and (3) how such an analysis provides an opportunity to explore the historical situatedness of conceptions of flourishing, an exploration that has the potential to make one's own conceptual assumptions more visible. Depending on the type of class one teaches, the guiding questions for student group work could be more or less explicit about these avenues of inquiry. This sensitivity to the positionality of both observer and observed is a crucial skill that we can likewise attempt to impart to our students and, once again, it is a technique that applies equally to considerations of the religious and the political.

The class might then, from this starting point, have space to consider how there is no universal way of responding to injustice, because there is no universally agreed upon way of articulating what constitutes agency and dignity. Yet the examples of Nadia and Sana reveal how both can agree that their shared experience has been unjust, despite the fact that their different values inform their engagement with their social worlds differently. Such agreement perhaps provides those who identify as feminists with a clearer sense of the forms that anti-oppressive action might take. In any case, detailed classroom consideration of the lives of these two women may help to illuminate how the acknowledgement of the fact that our ideas of agency are not universal does not, in itself, invalidate any particular conception of agency. It is simply a recognition that the norms through which we structure our lives are themselves always historically contingent. Understanding the self to be organized by an autonomous reasoning faculty, which then dictates one's actions and conditions one's experience of the world, is neither a universal conception nor a provable proposition, but rather a culturally contingent assumption naturalized by Western hegemony (Mahmood 2004, 11-12). ${ }^{9}$

\section{Positionality and Textual Interpretation}

Instructors might also incorporate readings that explicitly discuss the implications of positionality for textual interpretation. In a world that presents us with seemingly infinite data, positionality informs what we think of as requiring explanation, attention, or comment. As bell hooks observes, "combining the experiential and the analytical is a richer way of knowing" (1994, 89); likewise, Elaine Pagels reflects that "everything we experience shapes what we are capable of understanding" (2018, xiv). Studies and classroom activities that explicitly address how the identities and experiences of the interpreter operate in the activity of interpretation provide an opportunity to initiate a dialogue on this issue.

For example, one workshop participant, an instructor at a small liberal arts college, described an assignment designed to encourage students to explore positionality in textual interpretation-students write a blog post exploring how a think-piece or article in a major news publication is relevant for a particular audience and how it is relevant for a community to which the student belongs. Students then have an opportunity to respond to one another. Assessing how a singular text might be differently understood by

\footnotetext{
8 That is, while feminist inquiry can sometimes presuppose a liberationist teleology, that teleological narrative can fail to capture alternative ways in which women might conceptualize their own flourishing. Such strains of feminist discourse can, in this respect, end up demanding that women adopt as universal what are in fact historically contingent conceptions of well-being, at the expense of their own commitments and values: "Does a commitment to the ideal of equality in our own lives endow us with the capacity to know that this ideal captures what is or should be fulfilling for everyone else?" Mahmood asks. "If it does not, as is surely the case, then I think we need to rethink, with far more humility than we are accustomed to, what feminist politics really means" (2004, 38; cf. hooks 1994, 100-18). For another critique of the presumption of liberal notions of agency in historical work, see Johnson (2011).

9 Nicole Karapanagiotis offers another example of a teaching tactic meant to facilitate the goal of enabling students-particularly "missionary students" who take her class "to learn about other people's religions" with the unstated aim, as she surmises, of trying "to eradicate those religions"-to adopt a critical attitude toward their own positionality $(2017,47)$. For Karapanagiotis, this entails learning to participate in the academic study of religion as an endeavor committed to understanding others "on their own terms" (2017, 54-60), an endeavor she considers to require a suspension of values (2017, 62). Yet understanding someone "on their own terms" does not preclude, and in fact requires, an analysis of the historically contingent nature of those terms. Nor, moreover, does such an understanding preclude denaturalizing claims to authority, legitimacy, or authenticity, particularly insofar as such claims are made in relation to others and bear implications or assertions about what can and cannot be done to them. See also Wright (2019) and Fernandez (2015).
} 
different interpreters is a crucial skill for students and scholars of religious studies to exercise, and to make one of those interpreters the students themselves as they understand themselves to be aligned with a particular identity group amplifies the effect of this assignment on students' considerations of their own positionality. ${ }^{10}$ While it is important to be mindful of the risks that students might incur in this context, one of the advantages of this assignment is that the student can control the degree of disclosure in which they must actually engage. For instance, "a community to which the student belongs" might be the student body of the institution in which the class is conducted. Alternatively, students concerned about the risks of disclosure might be allowed to submit their assignment to the instructor instead of posting it for other students to read.

Another workshop participant, teaching a small interdisciplinary seminar at a midsized private research university, initiated dialogue on the effects of positionality on interpretation by having their students read and discuss Clarice Martin's essay, "Polishing the Unclouded Mirror: A Womanist Reading of Revelation 18:13" (2005). ${ }^{11}$ In this essay, Martin employs a womanist hermeneutic to read Revelation 18:3, highlighting the significance of John's indictment of slavery for his attack on Rome more generally. Martin describes womanist theory and analysis as "seek[ing] to dissolve and to dismantle the three-fold tyrannies of gender, race, and class as among the overarching and interlocking structures of domination in [the interpreters'] lives" (2005, 85). Privileging their own "identity and experience, womanist interpreters challenge the gender-exclusive hegemony of male-articulated understandings of the Christian faith" $(2005,85)$. Even as they struggle against the "twin evils" of androcentrism and patriarchy, womanist interpreters "also advance in solidarity with Black male interpreters against the idolatry and hegemony of White supremacy in traditional religion-the idolatry and hegemony that foster the evils of racist domination, ideology, interpretation, and oppression" (Martin 2005, 85). With such insights and affirmations in mind, Martin foregrounds John's critique of slavery, and is ultimately able to argue that ancient critics considered the Roman practice of slavery as more oppressive and dehumanizing than its apologists have argued.

Martin shows that John's critique of slavery has been overlooked and undertheorized by non-womanist interpreters. For instance, she draws special attention to how, in Revelation 18:12-13, John places enslaved people at the end of a list of commodities representing Roman excess. By comparing this to slavery's treatment in one of John's intertexts, a list in Ezekiel 27:12-25 which places enslaved people first, Martin is able to argue that John's placement "functions as a strategically crafted social critique of the widespread and 'taken for granted' practice of the slave trade in the pre-industrial, urban agrarian Mediterranean world of John's day" (2005, 99). By such arguments, Martin makes a convincing case that "John himself considered slavery in the Empire to be a horrendous, cruel, and dehumanizing institution" $(2005,101)$.

Martin's attention to these verses, her identification of comparanda, and her discussion of the theoretical lens she employs illustrate the contingency of interpretation (2005, 101-104). A different interpreter might situate John's critique of Rome against any number of other texts produced in the ancient period. Or a white interpreter might have had a reading similar to Martin's available to thembut might not, in fact, have emphasized these passages. As Martin explains, her attention is drawn to this particular verse, and the particular texts with which she brings it into conversation, as a consequence of her ethical commitments as a womanist interpreter, which are in turn rooted in her experiences as a Black American woman. At the same time, she rejects an essentializing understanding of interpretation: "A sustained engagement with Africana women does not require the presumption of an essentialist identity or a conflated 'homogeneity' of Africana women's experience” (Martin 2005, 86; cf. Pagels 2012). ${ }^{12}$

Martin's work provides an opportunity to explore with students how interpretations of historical texts that might seem obvious to them are, in fact, socially and historically conditioned by a variety of factors, among them the experiences of the interpreter. By engaging with literature that takes the question of positionality seriously, we can, with our students, reflect on the limitations of our own epistemological horizons, horizons that are at least in part shaped by our experiences as individuals and as members of communities.

10 Dallalfar (2011a) describes a similar assignment, in which students share personal responses to readings that draw upon their own experiences with the class as part of an examination of the feminist claim that "the personal is political." The theoretical insights gained in these discussions are then applied to other media Dallalfar introduces, particularly films, guest speakers, and images that the students bring in themselves (2011a, 121-2), as part of a project of constructing a "feminist global sociological imagination" (2011a, 124). In such assignments, Dallalfar, drawing on the work of Patricia Hill Collins, aims to help her students cultivate the position of "the outsider within" (2011a, 117; cf. Collins [1986]), though in this application what constitutes "the outside" and what constitutes "within" remain unarticulated.

11 In proposing alternative classroom strategies to those we have discussed here, both Sunanda Sanyal (2011) and Rajini Srikanth (2011) critique essentializing approaches to positionality while seeming to recognize inconsistently that it is possible to reject such essentialization without denying the function of positionality as such in teaching and research. While both point to the ways in which their own positionality has been operative in their teaching (Sanyal 2011, 132, 137-8; Srikanth 2011, 102), both also diminish the role of what Srikanth describes as "the specious and suspect authority of lived experience" (2011, 105; cf. Sanyal, 134, 137). For another compelling womanist perspective on Revelation that would work extremely well in the classroom, see Smith (2014).

12 On essentialization, see also, hooks (1994, 43-44). 


\section{The Embodied Performativity of the Instructor}

Finally, if instructors feel comfortable doing so, they might introduce positionality by explicitly using their own bodies as points of departure for conversation; for examples of such discussions, see McMillan Cottom's Thick and Other Essays (2019). ${ }^{13}$ Several femaleidentified workshop participants, for example, who teach at a wide variety of institutions, noted productively utilizing their performed gender in discussions of 1 Timothy 2:12, in which "Paul" declares, "I permit no woman to teach or have authority over a man." One workshop participant reported using this text as an opportunity to query the semiotics of the signifier "woman." If gender is a social construction, would not "woman" signify differently in the society of the second-century Mediterranean than it does in a contemporary American context?

Another workshop participant, a white instructor, made use of an activity incorporating Lloyd A. Thompson's book, Romans and Blacks (1989), a study that examines the valences of Roman representations of the Aethiops in the context of other Roman somatic types and in comparison with modern concepts of race and racism. Many of the negative stereotypes related to ethnicity were theorized in antiquity through the lens of environmental determinism. Excessively hot and cold climates impacted the character of those who inhabited them; the pale nordic barbarian was made brave but dim-witted by the cold, while the "black or near-black" inhabitants of the hot southern climes were sharp-witted but cowardly. The moderate climates of the Mediterranean, on this theory, produced the aesthetically and morally ideal human being (Thompson 1989, 101). Thompson's work might be paired with the studies of Gay Byron and David Brakke into early Christian representations of blackness (Byron 2002; Brakke 2001). In presenting this literature, a white instructor might situate their body in the context of these and other Roman and early Christian stereotypes, noting, for example, that many bodies-particularly male ones-racialized in the contemporary American context as white would have been categorized as barbarian in the Roman context (see also De La Torre 2015; Bazzano 2016, 276-82). In this regard, the white instructor's body can become a teaching tool for illustrating the historical contingency of categories of ethnicity, race, and racism. Such discussions also might be the starting point for consideration of the connections and disconnections between ancient versions of ethnic chauvinism and modern racism.

\section{Conclusion}

As educators, one of our central goals is to facilitate our students' understanding of the provisionality, contextuality, and contingency of knowledge production, a nexus of issues that is inextricable from questions of experience and its complex relationship to identity. Yet given the real, significant, and public risk disclosures pose to all students and instructors, but especially to those of marginalized identities, we have deemed it necessary to offer alternative or supplementary classroom strategies for discussing positionality. As we noted, given that the methods of the study of religion are aimed at the exploration of the relation of various identity claims to one another, and how those identity claims condition and are conditioned by interpersonal relationships and dynamics of power, these methods have a particular contribution to make to this endeavor. On the basis of the experiences of participants in our workshop, we have offered several recommendations for examining positionality's role in shaping cognition without requiring the risk that accompanies the disclosure of personal experience.

Responsible teaching and scholarship in any discipline require us to be able to investigate critically the manner in which a human being appears, an investigation that opens up a range of questions about how power, privilege, history, and experience shape those appearances. Attending to the nuances of positionality without requiring direct disclosure helps us and our students to come to terms with the idea that ultimately, our representations can never render humanity, of ourselves or of others, in its fullness. Our attempts at representation are always partial, are always asymptotal. ${ }^{14}$ Building a classroom responsive to this fact helps us, teacher and student, to mitigate the potential for harm to members of our classrooms, and to cultivate in ourselves the critical attitude towards one's assumptions, beliefs, conclusions, and methodologies that is the sine qua non of inquiry.

\footnotetext{
13 For an exploration of the potential for teacher embodiment to become a site for instruction, see Freedman and Stoddard Holmes (2003).

14 See Pagels: “Even now, writing about what's so deeply personal, I'm aware that anything I say can speak to you only as it resonates through what you have experienced yourself; yet even within those limits, we may experience mutual recognition" $(2018,208)$.
} 


\section{B I B LIOGRAPHY}

Ahmed, Sara. 2017. Living a Feminist Life. Durham, NC: Duke University Press.

Ayres, Lewis. 2004. Nicaea and its Legacy: An Approach to Fourth-Century Trinitarian Theology. Oxford, UK: Oxford University Press.

Baker, Cynthia M. 2017. Jew. New Brunswick, NJ: Rutgers University Press.

Bazzano, Elliott A., Audrey Truschke, and Jayme M. Yeo. 2016. "Forum: Insiders, Outsiders, and Disclosure in the Undergraduate Classroom." Teaching Theology and Religion 19: 276-95.

Berzon, Todd. 2016. “Identity, A Way Forward (Perhaps).” Ancient Jew Review, August 17. http://www.ancientjewreview.com/articles/2016/8/16/identity-a-way-forward-perhaps.

Boyarin, Daniel. 2006. Border Lines: The Partition of Judaeo-Christianity. Philadelphia, PA: University of Pennsylvania Press.

Brakke, David. 1994. “Canon Formation and Social Conflict in Fourth-Century Egypt: Athanasius of Alexandria's Thirty-Ninth 'Festal Letter.” The Harvard Theological Review 87: 395-419. https://doi.org/10.1017/S0017816000030200.

Brakke, David. 2001. "Ethiopian Demons: Male Sexuality, the Black-Skinned Other, and the Monastic Self." Journal of the History of Sexuality 10: 501-35. https://doi.org/10.1353/sex.2001.0049.

Brakke, David. 2003. “The Lady Appears: Materializations of 'Woman' in Early Monastic Literature.” Journal of Medieval and Early Modern Studies 33: 387-402. https://doi.org/10.1215/10829636-33-3-387.

Brakke, David. 2010a. The Gnostics: Myth, Ritual, and Diversity in Early Christianity. Cambridge, MA: Harvard University Press.

Brakke, David. 2010b. “A New Fragment of Athanasius's Thirty-Ninth Festal Letter: Heresy, Apocrypha, and the Canon." The Harvard Theological Review 103: 47-66. https://doi.org/10.1017/So017816009990307.

Burrus, Virginia. 2003. “Macrina’s Tattoo.” Journal of Medieval and Early Modern Studies 33: 403-417. https://doi.org/10.1215/10829636-33-3-403.

Butler, Judith. 1993. Bodies That Matter: On the Discursive Limits of “Sex." New York, NY: Routledge.

Byron, Gay. 2002. Symbolic Blackness and Ethnic Difference in Early Christian Literature. New York, NY: Routledge.

Campany, Robert Ford. 2003. "On the Very Idea of Religions (In the Modern West and in Early Medieval China)." History of Religions 42: 287-319. https://doi.org/10.1086/378757.

Clark, Elizabeth A. 1998. “The Lady Vanishes: Dilemmas of a Feminist Historian After the Linguistic Turn.” Church History 67: 1-31. https://doi.org/10.2307/3170769.

Collins, Patricia Hill. 1986. “Learning from the Outsider Within: The Sociological Significance of Black Feminist Thought." Social Problems 336: 14-32. https://doi.org/10.2307/800672.

Combahee River Collective. 2017. “The Combahee River Collective Statement.” In How We Get Free: Black Feminism and the Combahee River Collective, edited by Keeanga-Yamahtta Taylor, 15-28. Chicago, IL: Haymarket Books.

Cottine, Cheryl. 2016. "Role Modeling in an Early Confucian Context." The Journal of Value Inquiry 50: 797-819. https://doi.org/10.1007/s10790-016-9576-3. 
Crenshaw, Kimberlé W. 1989. "Demarginalizing the Intersection of Race and Sex: A Black Feminist Critique of Antidiscrimination Doctrine, Feminist Theory and Antiracist Politics.” University of Chicago Legal Forum 1: 139-67. https://chicagounbound. uchicago.edu/uclf/volig8g/iss1/8/.

Crenshaw, Kimberlé W. 1991. "Mapping the Margins: Intersectionality, Identity Politics, and Violence Against Women.” Stanford Law Review 43: 1241-1299. https://doi.org/10.2307/1229032.

Dallalfar, Arlene. 2011a. “Teaching Women’s Lives: Feminist Pedagogy and the Sociological Imagination.” In Transforming Classroom Culture: Inclusive Pedagogical Practices, edited by Dallalfar, Arlene, Esther Kingston-Mann, and Tim Sieber, 111-26. New York, NY: Palgrave MacMillan.

Dallalfar, Arlene, Esther Kingston-Mann, and Tim Sieber, eds. 2011b. Transforming Classroom Culture: Inclusive Pedagogical Practices. New York, NY: Palgrave MacMillan.

De La Torre, Miguel. 2015. "Identity Cross-dressing while Teaching in a Global Context." In Teaching Global Theologies: Power and Praxis, edited by Kwok, Pui-Lan, Cecilia González-Andrieu, and Dwight N. Hopkins, 75-89. Waco, TX: Baylor University Press.

Drake, Susanna. 2013. Slandering the Jew: Sexuality and Difference in Early Christian Texts. Philadelphia, PA: University of Pennsylvania Press.

Ehrlich, Thomas, and Anne Colby. 2004. "Political Bias in Undergraduate Education.” Liberal Education 90: 36-39. https://files.eric.ed.gov/fulltext/EJ682576.pdf.

Evans, David, and Tobin Miller Shearer. 2017. “A Principled Pedagogy for Religious Educators.” Religious Educators $112:$ 7-18. https://doi.org/10.1080/00344087.2016.1256367.

Fernandez, Eleazar S. 2015. “The Geopolitical and the Glocal: Situating Global Theological Voices in Theological Education.” In Teaching Global Theologies: Power and Praxis, edited by Pui-Lan, Kwok, Cecilia González-Andrieu, and Dwight N. Hopkins, 163-76. Waco, TX: Baylor University Press.

Frank, Georgia. 2000. “Macrina’s Scar: Homeric Allusion and Heroic Identity in Gregory of Nyssa's Life of Macrina.” Journal of Early Christian Studies 8: 511-30. https://muse.jhu.edu/article/10159.

Freedman, Diane, and Martha Stoddard Holmes, eds. 2003. The Teacher's Body: Embodiment, Authority, and the Identity in the Academy. Albany, NY: State University of New York Press.

Friedersdorf, Colin. 2012. “Admit it, American Colleges Do Indoctrinate Students.” The Atlantic, February 27. https://www.theatlantic.com/politics/archive/2012/02/admit-it-american-colleges-do-indoctrinate-students/253607/.

Fruchtman, Diane. 2015. “Sympathy for the Devil: Cultivating Critical Empathy Through Teaching Heterodoxy.” The Once and Future Classroom: Resources for Teaching 12. https://once-and-future-classroom.org/4-sympathy-for-the-devil-cultivating-critical-empathy-through-heterodoxy/.

Gayles, J. G., B. T. Kelly, S. Grays, J. J. Zhang, and K. P. Porter. 2015. “Faculty Teaching Diversity Through Difficult Dialogues: Stories of Challenges and Success." Journal of Student Affairs Research and Practice 52: 300-312. https://doi.org/10.1080/19 496591.2015 .1067223$.

Handelman, Don. 1977. “The Organization of Ethnicity.” Ethnic Groups 1: 187-200. https://www.researchgate.net/publication/262261605 The Organization of Ethnicity.

Herndl, Diane Price. 2003. “Johnny Mnemonic Meets the Bimbo: Feminist Pedagogy and Postmodern Discourse.” In The Teacher's Body: Embodiment, Authority, and the Identity in the Academy, edited by Freedman, Diane and Martha Stoddard Holmes, 59-68. Albany, NY: State University of New York Press.

hooks, bell. 1994. Teaching to Transgress: Education as the Practice of Freedom. New York, NY: Routledge. 
Hunter, David. 2009. Marriage, Celibacy, and Heresy in Early Christianity. Oxford, UK: Oxford University Press.

Ingraham, Christopher. 2016. “The Dramatic Shift Among College Professors That's Hurting Students’ Education.” Washington Post, January 11. https://www.washingtonpost.com/news/wonk/wp/2016/01/11/the-dramatic-shift-among-college-professors-thats-hurting-students-education/.

Iosif, Despina. 2013. Early Christian Attitudes to War, Violence, and Military Service. Piscataway, NJ: Gorgias.

Johnson, Walter. 2011. “Agency: A Ghost Story.” In Slavery's Ghost: The Problem of Freedom in the Age of Emancipation, edited by R. Follett, E. Foner, and W. Johnson, 8-30. Baltimore, MD: The Johns Hopkins University Press.

Karapanagiotis, Nicole. 2017. "(Inadvertently) Instructing Missionaries in (Public University) World Religions Courses: Examining a Pedagogical Dilemma, its Dimensions, and a Course Section Solution." Teaching Theology and Religion 20: 46-65. https://doi.org/10.1111/teth.12364.

Kelly, J.N.D. (1958) 2006. Early Christian Doctrines. New York, NY: Continuum.

Kelly-Woessner, April, and Matthew Woessner. 2006. “My Professor Is a Partisan Hack: How Perceptions of a Professor's Political Views Affect Student Course Evaluations.” PS: Political Science and Politics 39: 495-501. https://doi.org/10.1017/ S104909650606080X.

Kelly-Woessner, April, and Matthew Woessner. 2008. "Conflict in the Classroom: Considering the Effects of Partisan Difference on Political Education.” Journal of Political Science Education 4: 265-85. https://doi.org/10.1080/15512160802202789.

Kemmelmeier, Markus, Cherry Danielson, and Jay Basten. "What's in a Grade? Academic Success and Political Orientation." Personality and Social Psychology Bulletin 31: 1386-99. https://doi.org/10.1177/0146167205276085.

King, Karen. 2008. “Which Early Christianity?” In The Oxford Handbook of Early Christian Studies, 66-84. Oxford, UK: Oxford University Press.

Lahire, Bernard. 2001. The Plural Actor. Translated by David Fernbach. Cambridge, MA: Polity Press.

Larimer, Sarah. 2017. “An lowa Republican Wants Universities to Ask Prospective Professors: How Would You Vote?” Washington Post, February 22. https://www.washingtonpost.com/news/grade-point/wp/2017/02/22/an-iowa-republican-wants-universities-to-ask-prospective-professors-how-would-you-vote/.

Linvill, Darren, and Pamela Havice. 2011. "Political Bias in the Classroom-A Literature Review." Journal on Excellence and College Teaching 22: 67-83. http://celt. muohio.edu/ject/issue.php? $=22 \& n=2$.

Mahmood, Saba. 2004. Politics of Piety: The Islamic Revival and the Feminist Subject. Princeton, NJ: Princeton University Press.

Marbley, A, H., W. Ross, H. Burley, and F.A. Bonner II. 2009. "Teaching Diversity Across Disciplines: Reflections From African American Faculty In Four Different Academic Settings.” The Education Forum 74: 63-80. https://doi.org/10.1080/00131720903404031.

Martin, Clarice. 2005. "Polishing the Unclouded Mirror: A Womanist Reading of Revelation 18:13." In From Every People and Nation: The Book of Revelation in Intercultural Perspective, edited by David Rhoads, 82-109. Minneapolis, MN: Fortress Press.

Masuzawa, Tomoko. 2005. The Invention of World Religions: Or, How European Universalism Was Preserved in the Language of Pluralism. Chicago, IL: University of Chicago Press.

Mayhew, Matthew J., Alyssa N. Rockenbach, Benjamin S. Selznick, and Jay L. Zagorsky. 2018. “Does College Turn People into Liberals?” The Conversation, February 2. https://theconversation.com/does-college-turn-people-into-liberals-90905.

McMillan Cottom, Tressie. 2019. Thick and Other Essays. New York, NY: The New Press. 
Morrison, Toni. 2017. The Origin of Others. Cambridge, MA: Harvard University Press.

Moss, Jessica. 2012. Aristotle on the Apparent Good: Perception, Phantasia, Thought, and Desire. Oxford, UK: Oxford University Press.

Pagels, Elaine. 1976. “The Demiurge and his Archons': A Gnostic View of the Bishop and Presbyters?” The Harvard Theological Review 69: 301-24. https://doi.org/10.1017/S0017816000017491.

Pagels, Elaine. 1979. "Human Rights: Legitimizing a Recent Concept.” The Annals of the American Academy of Political and Social Science 442: 57-62. https://doi.org/10.1177/000271627944200107.

Pagels, Elaine. 2012. Revelations: Visions, Prophecy, and Politics in the Book of Revelation. New York, NY: Viking.

Pagels, Elaine. 2018. Why Religion? A Personal Story. New York, NY: HarperCollins.

Perlow, Olivia, Sharon Bethea, and Durene Wheeler. 2014. "Dismantling the Master's House: Black Women Faculty Challenging White Privilege/Supremacy in the College Classroom." Understanding and Dismantling Privilege 4, no. 2: $242-259$. http://www.wpcjournal.com/article/view/12307.

Poey, Vivian. 2011. “Imaging the Spaces Between Art and Inclusive Pedagogy.” Transforming Classroom Culture: Inclusive Pedagogical Practices, edited by Dallalfar, Arlene, Esther Kingston-Mann, and Tim Sieber, 77-93. New York, NY: Palgrave MacMillan.

Rebillard, Eric. 2012. Christians and Their Many Identities in Late Antiquity, North Africa 200-450 CE. Ithaca, NY: Cornell University Press.

Sandwell, Isabella. 2010. “John Chrysostom's Audiences and his Accusations of Religious Laxity." Late Antique Archaeology 6: 523-42. https://doi.org/10.1163/22134522-90000145.

Sanyal, Sunanda K. 2011. “Teaching Art History at an Art School: Making Sense from the Margin.” In Transforming Classroom Culture: Inclusive Pedagogical Practices, edited by Dallalfar, Arlene, Esther Kingston-Mann, and Tim Sieber, 127-39. New York, NY: Palgrave MacMillan.

Schott, Jeremy. 2008. Christianity, Empire, and the Making of Religion in Late Antiquity. Philadelphia, PA: University of Pennsylvania Press.

Shapiro, Ben. 2004. Brainwashed: How Universities Brainwash America's Youth. Nashville, TN: WND Books.

Smith, Shanell T. 2014. The Woman Babylon and the Marks of Empire: Reading Revelation with a Postcolonial Womanist Hermeneutics of Ambiveilence. Minneapolis, MN: Fortress Press.

Srikanth, Rajini. 2011. “Inexplicable Desire, Pedagogical Compulsion: Teaching the Literatures of the Middle East.” In Transforming Classroom Culture: Inclusive Pedagogical Practices, edited by Dallalfar, Arlene, Esther-Kingston Mann, and Tim Sieber, 95-110. New York, NY: Palgrave MacMillan.

Sweeney, Chris. 2016. “How Liberal Professors are Ruining College.” Boston Magazine, December 20. https://www.bostonmagazine.com/news/2016/12/20/liberal-professors/.

Thompson, Lloyd A. 1989. Romans and Blacks. Norman, OK: University of Oklahoma Press.

Upson-Saia, Kristi. 2011. Early Christian Dress: Gender, Virtue, and Authority. New York, NY: Routledge.

Upson-Saia, Kristi, Carly Daniel-Hughes, and Alicia Batten. 2014. Dressing Judeans and Christians in Antiquity. Farnham, UK: Ashgate. 
Upson-Saia, Kristi, and Maria Doerfler. 2020. "Politics and the Pedagogue of Late Antiquity." The Wabash Center Journal on Teaching 1, no. 3: 9-22. https://doi.org/10.31046/wabashcenter.v1i3.1785.

Westfield, Nancy Lynne, ed. 2008. Being Black, Teaching Black: Politics and Pedagogy in Religious Studies. Nashville, TN: Abington Press.

Wilhite, David. 2007. Tertullian the African: An Anthropological Reading of Tertullian's Context and Identities. New York, NY: de Gruyter.

Wilkinson, Kate. 2015. Women and Modesty in Late Antiquity. Cambridge, MA: Cambridge University Press.

Woessner, Matthew, and April Kelly-Woessner. 2009. "I Think My Professor is a Democrat: Considering Whether Students Recognize and React to Faculty Politics,” PS: Political Science and Politics 42: 343-52. https://doi.org/10.1017/ S1049096509090453.

Woessner, Matthew, and April Kelly-Woessner. 2015. "Reflections on Academic Liberalism and Conservative Criticism." Society 52: 35-41. https://doi.org/10.1007/s12115-014-9864-0.

Wright, Almeda. 2019. “Whose Voice Counts: Gender, Power, and Epistemologies in the Seminary Classroom.” Teaching Theology and Religion 22: 176-90. https://doi.org/10.1111/teth.12489.

\section{ABOUT THE AUTHORS}

Kathleen Gibbons is an independent scholar in early Christianity and author of The Moral Psychology of Clement of Alexandria (Routledge, 2016).

Diane Shane Fruchtman, Assistant Professor in the Religion Department at Rutgers University, is a scholar of Christian thought whose research explores rhetoric and the realities it helps construct, particularly in the realms of violence and martyrdom. She is currently working on a monograph, Surviving Martyrdom: Martyrdom Without Death in the Late Ancient Latin West and Beyond. 
